\title{
An overview of coping strategies used by patients after stroke
}

\author{
Katarína Dančová1, Tomáš Sollár'², Martina Romanová1 \\ ${ }^{1}$ Institute of Applied Psychology, Faculty of Social Sciences and Health Care, Constantine \\ the Philosopher University in Nitra \\ 2Department of Psychological Sciences, Faculty of Social Sciences and Health Care, \\ Constantine the Philosopher University in Nitra \\ katarina.dancova@ukf.sk, tsollar@ukf.sk,mromanova@ukf.sk
}

\begin{abstract}
There is growing empirical evidence that psychological factors such as personality, coping strategies, etc. play an important role in recovery after stroke. The objective of the present review was to provide an overview of current research on the relationship between coping and poststroke recovery. The findings of the study emphasize the specific role of coping strategies as a potential determinant of outcomes such as well-being, quality of life, recovery and depression after stroke. Several multidisciplinary databases available to the authors of this review were searched for studies published since 2010. Nine studies met the inclusion criteria. Most consistent findings suggest that coping strategies are substantial determinant of quality of life in patients after stroke and cause differences in perceiving subjective quality of life. A better understanding of the role of coping in poststroke recovery may be used in the process of rehabilitation. Methodological limits and suggestions for future research are discussed
\end{abstract}

Keywords: stroke, coping strategies, recovery, health-related quality of life, poststroke depression, poststroke fatigue, proactive coping.

\section{INTRODUCTION}

Stroke patients have high risk of death during the first weeks after the event, and between 20 and 50 percent die within the first month depending on type and severity, age, comorbidity, and severity of complications (Truelsen Nielsen, Boysen, \& Grønbaek, 2003). Stroke cause changes in people's lives, for both the long-term disability and the emotional aspects (World Health Organization, 2006). Many patients who survive the acute phase of stroke remain physically, socially, emotionally or cognitively impaired and need help from professionals or family caregivers (Anderson, Linto, Stewart-Wynne, 1995; Han \& Haley, 1999). The growing number of chronic stroke patients has led to growing interest in the consequences of stroke for health-related quality of life (Carod-Artal, Egido, González, \& de Seijas, 2000; Carod-Artal \& Egido, 2009; Teoh, Sims, \& Milgrom, 2009; Algurén, Fridlund, Cieza, Sunnerhagen, \& Christensson, 2012). Health related quality of life refers to "how health impacts on an individual's ability to function and his or her perceived well-being in physical, mental and social domains of life" (Coons, Rao, Keininger, \& Hays, 2000). Health-related quality of life is multidimensional construct, comprising different domains of one's life, such as physical, functional, psychological, and social health. Important determinants in the adjustment process after stroke are coping strategies, which reflect, the emotional, cognitive, and behavioural strategies people use to deal with the consequences of stroke (Darlington et al. 2009). Many stroke-specific education and self-management interventions aim to teach participants strategies to deal with the consequences of stroke (Forster et al. 2012; Lennon, McKenna, \& Jones, 2013). Coping strategies may influence functioning and health-related quality of life, because these factors reflect the way people approach stressful situations and react to them 
(Visser, Rhebergen, Rinkel, van Zandvoort, \& Post, 2009). Research has shown that stroke patients perceive lower health-related quality of life than the general population (Kauhanen et al., 2000) which is still the case five years after stroke (De Wit et al., 2016). In the study of Nijsse et al. (2017) the results show that more proactive coping was related to fewer cognitive complaints. Other factors that were significantly independently associated with coping were age, cognition and depressive symptoms, the last one being mostly related to quality of life.

\section{THE PRESENT STUDY}

The aim of the present study is to provide an overview of the current research examining the role of coping strategies in recovery of stroke survivors. This review aims to identify the variety of research objectives and most promising issues in current psychological research of the coping in stroke patients and its influence on recovery. In the present review study, we consider functional recovery, health-related quality of life, cognitive complaints, depression as terms that reflect various areas of recovery. These variables are related to health outcomes. They are indicators of the health status in stroke patients, which were evaluated in reviewed studies. And so, a better understanding of the role of coping in poststroke recovery may be useful in the process of rehabilitation (Kim et al., 2013).

\section{METHODS}

To provide a review of current research on the topic, a literature search covering the last ten yeras was carried out. To locate relevant research literature, the keywords stroke, coping, health-related quality of life, recovery, coping strategies were searched. Studies that were included in the review had to fit these four criteria - reporting primary research, using quantitative methods, published in English between 2010-2020, published in one of several multidisciplinary databases available to the authors of this review. Studies that did not meet the criteria were excluded from the review (e.g. studies that use qualitative methods, studies published as conference proceeding, thesis, or book chapter, studies published in other than English language). 9 out of 32 articles retrieved were relevant to the aim of the study and met the inclusion criteria. Studies fulfilling the inclusion criteria were further analysed from the perspective of the objectives, study design, sample, methods of data collection and key findings.

\section{RESULTS}

The search identified 9 articles that were relevant to the aim of the study. Basic information about reviewed studies (author, year, country, title of the study, design, sample, method, main findings) is presented in the table and more details are discussed in the following text.

Table 1 Studies included in the review (sorted in an ascending manner, according to the year of publishing)

\begin{tabular}{|c|c|c|c|}
\hline $\begin{array}{c}\text { Author } \\
\text { (year), } \\
\text { country }\end{array}$ & $\begin{array}{c}\text { Title of the } \\
\text { study }\end{array}$ & $\begin{array}{c}\text { Design, participants } \\
\text { and method } \\
\text { (method of } \\
\text { measurement, time } \\
\text { of measurement } \\
\text { after stroke) }\end{array}$ & Key findings \\
\hline $\begin{array}{c}\text { Wolters, } \\
\text { Stapert, } \\
\text { Brands, \& }\end{array}$ & $\begin{array}{c}\text { Coping styles in } \\
\text { relation to }\end{array}$ & $\begin{array}{l}\text { Longitudinal study } \\
\text { (assessment after } \\
\text { brain injury and at }\end{array}$ & $\begin{array}{c}\text { It was shown that the use of } \\
\text { passive coping styles in the } \\
\text { chronic phase was predictive }\end{array}$ \\
\hline
\end{tabular}




\begin{tabular}{|c|c|c|c|}
\hline $\begin{array}{c}\text { Van } \\
\text { Heugten } \\
\text { (2010) } \\
\text { The } \\
\text { Netherlands }\end{array}$ & $\begin{array}{c}\text { cognitive } \\
\text { rehabilitation } \\
\text { and } \\
\text { quality of life } \\
\text { after brain } \\
\text { injury }\end{array}$ & $\begin{array}{l}\text { least five months } \\
\text { after the start of } \\
\text { rehabilitation }) \\
\mathrm{n}=110(56.4 \% \text { male }) \text {, } \\
\text { mean age: } 45.1 \pm 12.8 \\
\text { Utrecht Coping List, } \\
\text { Stroke-Adapted } \\
\text { Sickness Impact } \\
\text { Profile, Life } \\
\text { Satisfaction } \\
\text { Questionnaire } 9 .\end{array}$ & $\begin{array}{l}\text { of less desirable quality of life } \\
\text { outcomes in the long term; } \\
\text { moreover, passive styles were } \\
\text { shown to be more prevalent in } \\
\text { the patients in the current } \\
\text { study compared to the general } \\
\text { population; results } \\
\text { demonstrated increases in } \\
\text { active problem-focused coping } \\
\text { styles and decreases in passive } \\
\text { emotion-focused coping styles, } \\
\text { over the course of and after } \\
\text { rehabilitation; these results } \\
\text { predicted a high quality of life } \\
\text { of patients. }\end{array}$ \\
\hline $\begin{array}{c}\text { van Mierlo, } \\
\text { Heugten, } \\
\text { Post, De } \\
\text { Kort, \& } \\
\text { Visser } \\
\text { (2015) } \\
\text { The } \\
\text { Netherlands }\end{array}$ & $\begin{array}{l}\text { Psychological } \\
\text { factors } \\
\text { determine } \\
\text { depressive } \\
\text { symptomatology } \\
\text { after stroke }\end{array}$ & $\begin{array}{l}\text { Cross-sectional study } \\
\text { n= 344 (64.0 \% } \\
\text { male), mean age: } \\
66.9 \pm 12.3 \\
\text { Hospital Anxiety and } \\
\text { Depression scale, } \\
\text { Eysenck Personality } \\
\text { Questionnaire } \\
\text { Revised Short Scale } \\
\text { (N-E), Life } \\
\text { Orientation Test- } \\
\text { Revised, General Self- } \\
\text { Efficacy Scale, Illness } \\
\text { Cognition } \\
\text { Questionnaire, } \\
\text { Proactive Coping } \\
\text { Competence List, } \\
\text { Utrecht Coping List, } \\
\text { Barthel Index, } \\
\text { Heteroanamnesis List } \\
\text { Cognition, National } \\
\text { Institutes of Health } \\
\text { Stroke Scale, } \\
\text { Montreal Cognitive } \\
\text { Assessment (patients } \\
\text { assessed at } 2 \text { months } \\
\text { poststroke). }\end{array}$ & $\begin{array}{l}\text { All psychological factors } \\
\text { investigated were bivariately } \\
\text { related to the presence of } \\
\text { depressive symptoms } 2 \\
\text { months poststroke; more } \\
\text { helplessness and passive } \\
\text { coping and less acceptance and } \\
\text { perceiving benefits were } \\
\text { identified as independent } \\
\text { predictors of the presence of } \\
\text { PSDS; more active coping } \\
\text { styles can reduce depressive } \\
\text { mood; passive coping styles } \\
\text { can increase feelings of } \\
\text { depression. }\end{array}$ \\
\hline $\begin{array}{l}\text { Tielemans, } \\
\text { Visser, } \\
\text { Schepers, } \\
\text { Post, \& Van } \\
\text { Heugten } \\
\text { (2014) }\end{array}$ & $\begin{array}{l}\text { Proactive coping } \\
\text { poststroke: } \\
\text { psychometric } \\
\text { properties of } \\
\text { the Utrecht } \\
\text { Proactive } \\
\text { Coping }\end{array}$ & $\begin{array}{l}\text { Cross-sectional study } \\
\mathrm{n}=55(50.9 \% \\
\text { male), mean age: } \\
58.7 \pm 12.8 \\
\text { mean time since } \\
\text { stroke: } 25.0 \pm 38.5 \\
\text { months }\end{array}$ & $\begin{array}{c}\text { Results supported the } \\
\text { proposed positive } \\
\text { associations between active } \\
\text { problem-based coping } \\
\text { strategies and } \\
\text { long-term health-related } \\
\text { quality of life; the associations }\end{array}$ \\
\hline
\end{tabular}




\begin{tabular}{|c|c|c|c|}
\hline $\begin{array}{c}\text { The } \\
\text { Netherlands }\end{array}$ & $\begin{array}{c}\text { Competence } \\
\text { Scale }\end{array}$ & $\begin{array}{l}\text { Stroke related factors } \\
\text { (stroke-affected } \\
\text { hemisphere, time } \\
\text { since stroke, type of } \\
\text { stroke, stroke } \\
\text { history), Barthel } \\
\text { Index, Utrecht } \\
\text { Proactive Coping } \\
\text { Competence scale, } \\
\text { Utrecht Coping List, } \\
\text { Short Stroke-Specific } \\
\text { Quality of Life Scale. }\end{array}$ & $\begin{array}{l}\text { of HRQOL with proactive } \\
\text { coping were stronger than } \\
\text { with other coping strategies } \\
\text { measured with the UCL; } \\
\text { moderate negative association } \\
\text { between proactive coping } \\
\text { strategies and time after } \\
\text { stroke. }\end{array}$ \\
\hline $\begin{array}{l}\text { Visser, } \\
\text { Aben, } \\
\text { Heijenbrok- } \\
\text { Kal, } \\
\text { Busschbach, } \\
\text { \& Ribbers } \\
\text { (2014) } \\
\text { The } \\
\text { Netherlands }\end{array}$ & $\begin{array}{l}\text { The relative } \\
\text { effect of coping } \\
\text { strategy and } \\
\text { depression on } \\
\text { health-related } \\
\text { quality of life in } \\
\text { patients in the } \\
\text { chronic phase } \\
\text { after stroke }\end{array}$ & $\begin{array}{l}\text { Cross-sectional study } \\
\text { n= } 213(56 \% \text { male), } \\
\text { mean age: } 59.0 \pm 9.86 \text {; } \\
\text { mean time since } \\
\text { stroke: } 53.0 \pm 37.8 \\
\text { months } \\
\text { The assimilative- } \\
\text { accommodative } \\
\text { coping } \\
\text { Scale, WHOQOL- } \\
\text { BREF, the Center for } \\
\text { Epidemiologic } \\
\text { Studies Depression } \\
\text { Scale, The short } \\
\text { version of the Token } \\
\text { Test, demographic } \\
\text { and clinical } \\
\text { characteristics, } \\
\text { were obtained from } \\
\text { patient } \\
\text { records and a } \\
\text { structured interview } \\
\text { by the research } \\
\text { psychologist prior } \\
\text { to the measurement. }\end{array}$ & $\begin{array}{l}\text { In } 73.1 \% \text { of patients the } \\
\text { accommodative coping } \\
\text { strategy was more prominent } \\
\text { than the assimilative coping } \\
\text { strategy. Depression and } \\
\text { accommodative coping are } \\
\text { strongly related to all } 4 \\
\text { domains } \\
\text { of HRQoL. Accommodative } \\
\text { coping strategy is also strongly } \\
\text { related to HRQoL, but not } \\
\text { independent of depression. } \\
\text { This may be caused by the } \\
\text { inverse relationship between } \\
\text { coping strategy and } \\
\text { depression: patients } \\
\text { who prefer an accommodative } \\
\text { coping strategy show fewer } \\
\text { symptoms of depression and } \\
\text { had a higher HRQOL. Time } \\
\text { postonset, type of stroke and } \\
\text { side of stroke were not related } \\
\text { to any of the domains of } \\
\text { HRQoL Accommodative coping } \\
\text { was an independent } \\
\text { contributor } \\
\text { to Psychological Health. The } \\
\text { domains Physical Health, } \\
\text { Social Relationships and } \\
\text { Environment appear to differ } \\
\text { from the domain Psychological } \\
\text { Health because these domains } \\
\text { depend more on external } \\
\text { factors. Other variables, such } \\
\text { as severity of aphasia, living } \\
\text { without a partner and higher } \\
\text { education were more }\end{array}$ \\
\hline
\end{tabular}




\begin{tabular}{|c|c|c|c|}
\hline & & & $\begin{array}{l}\text { important than coping } \\
\text { strategies in these domains. }\end{array}$ \\
\hline $\begin{array}{c}\text { Nijsse, van } \\
\text { Heugten, } \\
\text { van Mierlo, } \\
\text { Post, de } \\
\text { Korta \& } \\
\text { Visser } \\
\text { (2015) } \\
\text { The } \\
\text { Netherlands }\end{array}$ & $\begin{array}{l}\text { Psychological } \\
\text { factors are } \\
\text { associated with } \\
\text { subjective } \\
\text { cognitive } \\
\text { complaints } 2 \\
\text { months post- } \\
\text { stroke }\end{array}$ & $\begin{array}{l}\text { Cross-sectional study, } \\
\text { part of the } \\
\text { prospective } \\
\text { longitudinal } \\
\text { Restore4Stroke } \\
\text { cohort study } \\
\mathrm{n}=350 \text { (63.7\% male), } \\
\text { mean age: } 66.6 \pm 12.4 \\
\text { Checklist for } \\
\text { Cognitive and } \\
\text { Emotional } \\
\text { consequences } \\
\text { following stroke, the } \\
\text { National Institutes of } \\
\text { Health Stroke Scale, } \\
\text { Barthel Index, } \\
\text { Cumulative Illness } \\
\text { Rating Scale, } \\
\text { Montreal Cognitive } \\
\text { Assessment, Hospital } \\
\text { Anxiety and } \\
\text { Depression Scale, } \\
\text { Proactive Coping } \\
\text { Competence } \\
\text { Inventory, Utrecht } \\
\text { Coping List, General } \\
\text { Self-Efficacy Scale, } \\
\text { Life Orientation Test- } \\
\text { Revised, Eysenck } \\
\text { Personality } \\
\text { Questionnaire- } \\
\text { Revised Short Scale } \\
\text { (assessed at stroke } \\
\text { onset and } 2 \text { months } \\
\text { post-stroke). }\end{array}$ & $\begin{array}{l}\text { The most reported cognitive } \\
\text { complaints were mental } \\
\text { slowness, attention problems } \\
\text { and memory problems for new } \\
\text { information; all psychological } \\
\text { factors investigated were } \\
\text { bivariately related to cognitive } \\
\text { complain; Analyses showed } \\
\text { that more depressive } \\
\text { symptoms, more anxiety, less } \\
\text { proactive coping, more passive } \\
\text { coping were significantly } \\
\text { associated with higher scores } \\
\text { on the CLCE-24 cognition } \\
\text { domain; the proactive coping } \\
\text { was the most predictor of great } \\
\text { cognitive complaints from all } \\
\text { psychological variables. }\end{array}$ \\
\hline $\begin{array}{c}\text { Visser, } \\
\text { Heijenbrok- } \\
\text { Kal, van't } \\
\text { Spijker, } \\
\text { Oostra, } \\
\text { Busschbach, } \\
\text { \& Ribbers } \\
\text { (2015) }\end{array}$ & $\begin{array}{c}\text { Coping, } \\
\text { Problem } \\
\text { Solving, } \\
\text { Depression, } \\
\text { and } \\
\text { Health-Related } \\
\text { Quality of Life } \\
\text { in Patients } \\
\text { Receiving } \\
\text { Outpatient } \\
\text { Stroke } \\
\text { Rehabilitation } \\
\end{array}$ & $\begin{array}{l}\text { Cross-sectional study } \\
\mathrm{n}=166(53 \% \\
\text { male), mean age: } \\
53.06 \pm 10.19 \\
\text { median time } \\
\text { poststroke: } 7.29 \\
\text { months } \\
\text { five-level EuroQol } \\
\text { five-dimensional } \\
\text { questionnaire, Stroke- } \\
\text { Specific Quality of Life } \\
\text { Scale, Coping }\end{array}$ & $\begin{array}{l}\text { This study supported the } \\
\text { hypothesis that patients with } \\
\text { high and low depression scores } \\
\text { receiving outpatient stroke } \\
\text { rehabilitation use different } \\
\text { coping strategies and problem- } \\
\text { solving skills. } \\
\text { 39.2\% of the study population } \\
\text { reported high depression } \\
\text { scores. Time poststroke was } \\
\text { not related to depression. } \\
\text { Depression score had the }\end{array}$ \\
\hline
\end{tabular}




\begin{tabular}{|c|c|c|c|}
\hline $\begin{array}{c}\text { The } \\
\text { Netherlands } \\
\text { and } \\
\text { Belgium }\end{array}$ & & $\begin{array}{l}\text { Inventory for } \\
\text { Stressful Situations, } \\
\text { Social Problem- } \\
\text { Solving Inventory } \\
\text { Revised: Short } \\
\text { Form, the Center for } \\
\text { Epidemiologic Studies } \\
\text { Depression Scale, } \\
\text { Token Test, The } \\
\text { modified Rankin } \\
\text { Scale, demographic } \\
\text { and clinical } \\
\text { characteristics, } \\
\text { were obtained from } \\
\text { patient } \\
\text { records and a } \\
\text { structured interview }\end{array}$ & $\begin{array}{l}\text { strongest relation with HRQOL. } \\
\text { Those with high depression } \\
\text { scores were younger and more } \\
\text { frequently women, living } \\
\text { without a partner, and had } \\
\text { ischemic stroke, had a lower } \\
\text { value to all HRQOL domains, } \\
\text { used more emotion-oriented } \\
\text { coping strategies, and } \\
\text { avoidance style, and used total } \\
\text { positive problem-solving skills } \\
\text { less frequently. Emotion- } \\
\text { oriented coping was not } \\
\text { independently related to } \\
\text { HRQOL. This coping strategy } \\
\text { and the problem-solving skills } \\
\text { and avoidance style were only } \\
\text { indirectly related to HRQOL. } \\
\text { This is in line with data from a } \\
\text { large randomized controlled } \\
\text { trial showing that problem- } \\
\text { solving therapy had a positive } \\
\text { effect on depression. }\end{array}$ \\
\hline $\begin{array}{l}\text { Wei, Zhang, } \\
\text { F., Chen, Ma, } \\
\text { Zhang, N., \& } \\
\text { Hao (2016) } \\
\text { China }\end{array}$ & $\begin{array}{c}\text { Factors } \\
\text { associated with } \\
\text { post-stroke } \\
\text { depression and } \\
\text { fatigue: lesion } \\
\text { location and } \\
\text { coping styles }\end{array}$ & $\begin{array}{l}\text { Descriptive, cohort } \\
\text { study } \\
\mathrm{n}=368 \text { (29\% female), } \\
\text { mean age: } 61.6 \pm 9.8 \\
\text { (at admission and } 3 \\
\text { months after stroke) } \\
\text { Beck Depression } \\
\text { Inventory, Fatigue } \\
\text { severity scale, the } \\
\text { Mini-Mental State } \\
\text { Examination, Social } \\
\text { Support Rating Scale, } \\
\text { Medical Coping } \\
\text { Modes } \\
\text { Questionnaire, MRI, }\end{array}$ & $\begin{array}{l}\text { PSD was diagnosed in } 19.3 \% \\
\text { of the patients at admission } \\
\text { and in } 23.6 \% \text { at } 3 \text { months. PSF } \\
\text { was present in } 23.4 \% \text { of the } \\
\text { patients at admission and in } \\
29.6 \% \text { at } \\
3 \text { months. The patients who } \\
\text { manifested a lower degree of } \\
\text { social utilization and chose } \\
\text { avoidance coping styles were } \\
\text { more prone to PSD. Moreover, } \\
\text { acceptance-resignation styles, } \\
\text { low objective support } \\
\text { and degree of social utilization } \\
\text { were also predictive factors for } \\
\text { PSF. The appearance of PSD } \\
\text { was not related to lesion } \\
\text { location. A low degree of social } \\
\text { utilization was the } \\
\text { independent factor } \\
\text { associated with PSD and PSF at } \\
3 \text { months after stroke. } \\
\text { Acceptance-resignation } \\
\text { independently related to PSD } \\
\text { and }\end{array}$ \\
\hline
\end{tabular}




\begin{tabular}{|c|c|c|c|}
\hline & & & $\begin{array}{c}\text { PSF both at admission and } 3 \\
\text { months after stroke. Avoidance } \\
\text { was the independent factor } \\
\text { related to PSD at } 3 \text { months, } \\
\text { whereas confrontation was the } \\
\text { indepen dent factor related to } \\
\text { PSF at } 3 \text { months after stroke } \\
\text { onset. }\end{array}$ \\
\hline $\begin{array}{l}\text { van Mierlo, } \\
\text { Heugten, } \\
\text { Post, } \\
\text { Hoekstra, \& } \\
\text { Visser } \\
\text { (2017) } \\
\text { The } \\
\text { Netherlands }\end{array}$ & $\begin{array}{l}\text { Trajectories of } \\
\text { health-related } \\
\text { quality of life } \\
\text { after stroke: } \\
\text { results from a } \\
\text { one-year } \\
\text { prospective } \\
\text { cohort study }\end{array}$ & $\begin{array}{l}\text { Longitudinal design } \\
\text { n= } 351 \text { ( } 64.4 \% \text { male), } \\
\text { mean age: } 66.8 \pm 12.5 \\
\text { Short Stroke Specific } \\
\text { Quality of Life Scale } \\
\text { (2,6 and } 12 \text { months } \\
\text { after stroke), Eysenck } \\
\text { Personality } \\
\text { Questionnaire } \\
\text { Revised Short Scale } \\
\text { (N-E), Life } \\
\text { Orientation Test- } \\
\text { Revised, General Self- } \\
\text { Efficacy Scale, Illness } \\
\text { Cognition } \\
\text { Questionnaire, } \\
\text { Utrecht Proactive } \\
\text { Coping Competence } \\
\text { List, Utrecht Coping } \\
\text { List (2 months post } \\
\text { stroke), } \\
\text { Heteroanamnesis List } \\
\text { Cognition, National } \\
\text { Institutes of Health } \\
\text { Stroke Scale (4 days } \\
\text { after stroke), } \\
\text { Cumulative Illness } \\
\text { Rating scale, Montreal } \\
\text { Cognitive Assessment, } \\
\text { Barthel Index ( } 4 \text { days } \\
\text { and } 2 \text { months after } \\
\text { stroke) }\end{array}$ & $\begin{array}{c}\text { Four trajectories were } \\
\text { identified for both physical and } \\
\text { psychosocial HRQoL: stable } \\
\text { high, stable low, recovery, and } \\
\text { decline. } \\
\text { Compared with the patients in } \\
\text { the high psychosocial HRQoL } \\
\text { patients who had low physical } \\
\text { HRQoL were more likely to } \\
\text { have higher scores for } \\
\text { neuroticism, pessimism, } \\
\text { feelings of helplessness and } \\
\text { passive coping, and to have } \\
\text { lower scores for proactive } \\
\text { coping. Patients in the decline } \\
\text { trajectory were more likely to } \\
\text { feelings of helplessness and } \\
\text { passive coping. Compared with } \\
\text { the patients in the high } \\
\text { physical HRQoL trajectory } \\
\text { patients in the decline } \\
\text { trajectory were more likely to } \\
\text { have higher scores for } \\
\text { helplessness and passive } \\
\text { coping, and to have lower } \\
\text { scores for proactive coping. } \\
\text { Decline and high trajectories } \\
\text { yielded the following } \\
\text { predictors of physical HRQoL: } \\
\text { passive coping. Predictors of } \\
\text { psychosocial HRQoL were: less } \\
\text { proactive coping, and more } \\
\text { passive coping. }\end{array}$ \\
\hline $\begin{array}{c}\text { Solgajová, } \\
\text { Vörösová, \& } \\
\text { Zrubcová } \\
\text { (2017) } \\
\text { Slovakia }\end{array}$ & $\begin{array}{c}\text { Determinants } \\
\text { of quality of life } \\
\text { in patients after } \\
\text { stroke }\end{array}$ & $\begin{array}{l}\text { Cross-sectional study } \\
\mathrm{n}=60 \text { (55\% male), } \\
\text { mean age: } 63.7 \pm 11.2 \\
\text { Short Form }-36, \\
\text { Proactive Coping } \\
\text { Inventory (data } \\
\text { collected } 1 \text { month } \\
\text { after stroke). }\end{array}$ & $\begin{array}{l}\text { The level of quality of life is } \\
\text { strongly affected by various } \\
\text { proactive coping strategies, the } \\
\text { scale of proactive coping is } \\
\text { largely associated with all } \\
\text { domains of quality of life of } \\
\text { patients; }\end{array}$ \\
\hline
\end{tabular}


Pomáhajúce profesie, roč. 2, č. 2, 2019, 5-17

\begin{tabular}{|l|c|c|}
\hline & & Coping strategies are \\
& & substantial determinant of \\
& quality of life of patients after \\
& stroke and cause differences in \\
& perceiving subjective quality of \\
& & life of patients. \\
\hline
\end{tabular}

\section{DISCUSSION}

The aim of the present study was to review current literature on coping strategies in relation to outcome of stroke survivors. Most studies were carried out in the Netherlands, only three of them report data from Belgium, China and Slovakia.

\section{Objectives of the reviewed studies}

The main objective of the reviewed studies was to critically evaluate the findings concerning the effect of coping on patients' recovery. Our study offers a wide range of research in this field. Wolters, Stapert, Brands, \& Van Heugten (2010) examined the changes in coping styles in patients with acquired brain injury who underwent cognitive rehabilitation, and the effects of these changes on their quality of life. Van Mierlo, Heugten, Post, De Kort, \& Visser (2015) focused on to identify psychological factors related to poststroke depressive symptoms. Tielemans, Visser, Schepers, Post, \& Van Heugten (2014) explored relations of proactive coping with health-related quality of life (HRQOL) and characteristics of patients with stroke. Visser, Aben, Heijenbrok-Kal, Busschbach, \& Ribbers (2014) explored the relative associations of coping strategies and depression on healthrelated quality of life in patients in the chronic phase after stroke. Nijsse, van Heugten, van Mierlo, Post, de Korta \& Visser (2015) inestigated which psychological factors were related to post-stroke subjective cognitive complaints, taking into account the influence of demographic and strokerelated characteristics, cognitive deficits and emotional problems. Visser, Heijenbrok-Kal, van't Spijker, Oostra, Busschbach, \& Ribbers (2015) investigated whether patients with high and low depression scores after stroke used different coping strategies and problem-solving skills and whether these variables were related to psychosocial health-related quality of life (HRQOL) independent of depression. Wei, Zhang, F., Chen, Ma, Zhang, N., \& Hao (2016) evaluated PSD and PSF at different stages after cerebral infarction and attempted to correlate patients' symptoms with lesion location, coping styles and other variables. Van Mierlo, Heugten, Post, Hoekstra, \& Visser (2017) aimed to identify trajectories of physical and psychosocial health-related quality of life from two months to one-year post stroke and to determine the factors associated with trajectory membership and Solgajová, Vörösová, \& Zrubcová (2017) examined the patients' quality of life in first month after stroke and assessed the impact of selected determinants: age, sex, type of stroke, proactive coping strategies.

\section{Designs of the reviewed studies}

Most of the reviewed studies (Van Mierlo et al., 2015; Tielemans, Visser et al., 2014; Visser et al., 2014; Nijsse et al., 2015; Visser et al., 2015, Solgajová et al., 2017) had a cross-sectional design, which is suitable in this field. Another research design was longitudinal or cohort study (Wolters et al., 2010; Wei et al., 2016; Van Mierlo et al., 2017). Longitudinal design allows examining the changes in coping or quality of life during recovery after stroke and may propose the most relevant solutions in rehabilitation with the goal to improved quality of life of patients.

\section{Measurement tools of the reviewed studies}




\section{Pomáhajúce profesie, roč. 2, č. 2, 2019, 5-17}

The measurement tools in the reviewed studies that examine coping strategies were different, but the most often Utrecht Coping List and Proactive Coping Competence List were used. In study of Wolters et al. (2010) the Utrecht Coping List, Stroke-Adapted Sickness Impact Profile were used, van Mierlo et al. (2015) used Proactive Coping Competence List, Utrecht Coping List, Tielemans et al. (2014) used Utrecht Proactive Coping Competence scale, Utrecht Coping List, Visser et al. (2014) used the assimilative-accommodative coping Scale. In their study Nijsse et al. (2015) Proactive Coping Competence Inventory, Utrecht Coping List were used, Visser et al. (2015) used Coping Inventory for Stressful Situations, Social Problem-Solving Inventory Revised: Short Form, Wei et al. (2016) used Medical Coping Modes Questionnaire, van Mierlo et al. (2017) used Utrecht Proactive Coping Competence List, Utrecht Coping List and Solgajová et al. (2017) used Proactive Coping Inventory.

\section{Specific coping strategies examined in the reviewed studies}

In the reviewed studies, coping was examined as proactive coping (Nijsse et al., 2015; Solgajová et al., 2017; Tielemans et al., 2014; van Mierlo et al., 2015; van Mierlo et al., 2017) passive coping (Nijsse et al., 2015; van Mierlo et al., 2015; van Mierlo et al., 2017; Wolters et al., 2010), as assimilative or accommodative coping (Visser et al., 2014), as problem-focused or emotion-focused coping (Visser et al., 2015; Wolters et al., 2010), and as confrontation, avoidance and acceptance resignation coping (Wei et al., 2016).

The recovery or survival of patients are defined as well-being or quality of life (Solgajová et al., 2017; Tielemans et al., 2014; van Mierlo et al., 2017; Visser et al., 2014; Visser et al., 2015) or cognitive complaints (Nijsse et al., 2015) or presence of depressive symptoms/poststroke depression (van Mierlo et al., 2015; Visser et al., 2014; Visser et al., 2015; Wei et al., 2016) or poststroke fatigue (Wei et al., 2016).

\section{The main findings of the reviewed studies}

The most consistent findings from all reviewed studies are that coping strategies are crucial to maintain recovery and they are strongly associated with health-related quality of life in all time points after stroke as well as depression (Nijsee et al., 2015; van Mierlo et al., 2015; Visser et al., 2015; Wei et al., 2015). The adaptive coping strategies increased the health-related quality of life while maladaptive coping strategies decreased the health-related quality of life. Accommodative coping (flexibility) as adaptive coping strategy is independently related to Psychological Health in the chronic phase after stroke. The findings indicate that, regardless of the presence of depressive symptoms, accommodative coping positively influences Psychological Health (Visser et al., 2014). Van Mierlo et al. (2017) found that predictors of physical health- related quality of life was passive coping and predictors of psychosocial health-related quality of life were less proactive coping, and more passive coping. Solgajová et al. (2017) found out that proactive coping strategy is a substantial determinant of quality of life in patients after stroke and causes differences in perceiving subjective quality of life.

Research also indicat that the effects of coping on quality of life become stronger in the chronic phase post-stroke, while the effects of general functioning become less important (Darlington et al., 2007). Using maladaptive coping such as passive coping is most prevalent in the chronic phase. In study of Wolters et al. (2010) levels of active problem-focused coping styles decreased, and passive emotion-focused coping styles increased over the course of and after rehabilitation (Wolters et al., 2010). Ben-Yishay (2008) and Goldstein (1952) postulated that in order to restore the patient's cognitive and functional life competencies to pre-injury levels, caregivers and family members must structure and modify the patient's environment so that the patient will be able to cope with the demands of confronting situations. Under those conditions, the patient will feel "in a 
state of health" and display or report active problem-focused coping styles. While this feeling is fostered during rehabilitation programmes, it could be lost or altered when rehabilitation comes to an end.

In studies in which the recovery or survival of patients was defined as depression, it was found out that more passive coping was identified as independent predictors of the presence of poststroke depression 2 months poststroke. Whereas more active coping styles can reduce depressive mood, passive coping styles can increase feelings of depression. So, coping strategies can cause the presence of depression in patients after stroke (van Mierlo et al., 2015; Wei et al., 2015). Patients with high depression scores after stroke used more emotion-oriented coping, and avoidance style and less positive problem-solving skills (Visser et al., 2015). The study in which the recovery or survival of patients was defined as the level of cognitive complaints it was found out that more proactive coping was related to fewer cognitive complaints and other factors that were significantly independently associated with coping were age, cognition and depressive symptoms, the last one being most strongly related (Nijsse et al., 2015).

The findings also indicat that the effects of coping strategies on stroke related factors were not examined in all studies. In most studies, stroke related factors were not significantly related to health-related quality of life. Nowadays, it is well known that psychological variables are more important determinant of health-related quality of life that clinical variables. This assumption was also supported by the results of the reviewed studies. None of the demographic and stroke-related factors were significant determinants of PSDS in bivariate analyses, except for cognitive functioning (van Mierlo et al., 2015). No association was found between the level of independence in basic activities of daily living and proactive coping strategies (Tielemans et al., 2014). The relationship between PSF and lesion location was not significant during the acute stage indicating that the redistribution of neurotransmitters may take some time (Wei et al., 2015). Sex, living without a partner, education level, side and type of stroke, and severity of aphasia were not related to any HRQoL domains (Visser et al., 2015).

\section{Strengths and limitations of the study}

The strength of our study can be found in evaluation of different type of research designs and outcomes of research studies related to poststroke recovery. Our intention was to take into account various coping strategies, e.g. proactive coping, passive coping, assimilative or accommodative coping, problem-focused or emotion-focused coping, confrontation, avoidance and acceptance resignation coping. Most of the reviewed studies examined proactive coping strategy. This is in line with the growing number of researchers proposing that the broad spectrum of coping is not adequately captured by the traditional dichotomy as problem-based or emotion-based coping strategies. As a reaction, several new classifications of coping have been proposed in terms of new subdivisions of coping and classifications at higher order levels; the concept of proactive coping is one of these new forms (Tielemans et al., 2014). This literature review offers an overview of articles since 2010, in which coping stands as an independent variable influencing recovery after stroke.

Several study limitations should be addressed. First, the results may be influenced by the use of various questionnaires measuring the outcome variables, various cut-off scores used to determine the diagnosis, or various sources of information (self-report vs. informant rating). In some studies, the data were collected from the informants, usually the caregivers (e.g. spouse, son or daughter). Their ratings may be affected by their own personality or current distress caused by caring for their relatives after stroke. Another issue is related to a "healthy recruitment bias" which means that patients with more serious health status or cognitive impairment did not participate in the study. 
Patients were the most frequently recruited with mild or moderate stroke, but not with severe stroke. As a result, the samples may not represent general stroke population.

\section{CONCLUSION}

The objective of the present review was to provide an overview of current research on the relationship between coping and poststroke recovery. The findings of the study emphasize the specific role of coping strategies as a potential determinant of outcomes such as well-being, quality of life, recovery and depression after stroke. The adaptive coping strategies increased the healthrelated quality of life while maladaptive coping strategies decreased the health-related quality of life. It is very important, and it may be beneficial to target patients' coping strategies in poststroke rehabilitation programmes to improving the health-related quality of life, which is still the case of health psychology. Backhaus, Ibarra, Klyce, Trexler \& Malec (2010) show that an intervention was beneficial in changing maladaptive coping strategies in traumatic brain-injured patients. In patients after stroke, Darlington et al. (2009) show that over time, the importance of general functioning in determining health-related quality of life diminishes, whereas coping becomes more important. The findings indicate that psychological factors are the most important factors associated with HRQoL. Determining these predictors as early as two months post stroke will help to identify those patients at risk of unfavorable physical and psychosocial health-related quality of life trajectories, and to guide rehabilitation in the early stages post stroke (van Mierlo et al., 2017).

\section{REFERENCES}

Algurén, B., Fridlund, B., Cieza, A., Sunnerhagen, K. S., \& Christensson, L. (2012). Factors associated with health-related quality of life after stroke: a 1-year prospective cohort study. Neurorehabilitation and neural repair, 26(3), 266-274. Doi: 10.1177/1545968311414204.

Anderson, C. S., Linto, J., \& Stewart-Wynne, E. G. (1995). A population-based assessment of the impact and burden of caregiving for long-term stroke survivors. Stroke, 26(5), 843-849. Doi: 10.1161/01.str.26.5.843.

Backhaus, S. L., Ibarra, S. L., Klyce, D., Trexler, L. E., \& Malec, J. F. (2010). Brain injury coping skills group: a preventative intervention for patients with brain injury and their caregivers. Archives of physical medicine and rehabilitation, 91(6), 840-848. Doi: 10.1016/j.apmr.2010.03.015.

Ben-Yishay, Y. (2008). Foreword. Neuropsychological Rehabilitation, 18(5-6), 513-521. Doi: 10.1080/09602010802141525.

Carod-Artal, F. J., \& Egido, J. A. (2009). Quality of life after stroke: the importance of a good recovery. Cerebrovascular diseases, 27(Suppl. 1), 204-214. Doi: 10.1159/000200461.

Carod-Artal, J., Egido, J. A., González, J. L., \& Varela de Seijas, E. (2000). Quality of life among stroke survivors evaluated 1 year after stroke: experience of a stroke unit. Stroke, 31(12), 2995-3000. Doi: 10.1161/01.STR.31.12.2995.

Coons, S. J., Rao, S., Keininger, D. L., \& Hays, R. D. (2000). A comparative review of generic qualityof-life instruments. Pharmacoeconomics, 17(1), 13-35. Doi: 10.2165/00019053-20001701000002.

Darlington, A. S. E., Dippel, D. W., Ribbers, G. M., van Balen, R., Passchier, J., \& Busschbach, J. J. (2009). A prospective study on coping strategies and quality of life in patients after stroke, assessing 
prognostic relationships and estimates of cost-effectiveness. Journal of Rehabilitation Medicine, 41(4), 237-241. Doi: 10.2340/16501977-0313.

De Wit, L., Theuns, P., Dejaeger, E., Devos, S., Gantenbein, A. R., Kerckhofs, E., ... \& Putman, K. (2017). Long-term impact of stroke on patients' health-related quality of life. Disability and rehabilitation, 39(14), 1435-1440. Doi: 10.1080/09638288.2016.1200676.

Forster, A., Brown, L., Smith, J., House, A., Knapp, P., Wright, J. J., \& Young, J. (2012). Information provision for stroke patients and their caregivers. Cochrane Database of Systematic Reviews, 1(11). Doi: 10.1002/14651858.CD001919.pub3.

Goldstein, K. (1952). The effect of brain damage on the personality. Psychiatry, 15(3), 245-260.

Han, B., \& Haley, W. E. (1999). Family caregiving for patients with stroke: review and analysis. Stroke, 30(7), 1478-1485. Doi: 10.1161/01.str.30.7.1478.

Kauhanen, M. L., Korpelainen, J. T., Hiltunen, P., Nieminen, P., Sotaniemi, K. A., \& Myllylä, V. V. (2000). Domains and determinants of quality of life after stroke caused by brain infarction. Archives of physical medicine and rehabilitation, 81(12), 1541-1546. Doi: 10.1053/apmr.2000.9391.

Kim, S. Y. Kim, J.M., Stewart, R., Kang, H.J., Kim, S.W., Shin, I.S.....Yoon, J. S. (2013). Influences of personality traits on quality of life after stroke. European neurology, 69(3), 185-192. Doi: 10.1159/000345699.

Lennon, S., McKenna, S., \& Jones, F. (2013). Self-management programmes for people post stroke: a systematic review. Clinical Rehabilitation, 27(10), 867-878. Doi: 10.1177/0269215513481045.

Nijsse, B., van Heugten, C. M., van Mierlo, M. L., Post, M. W., de Kort, P. L., \& Visser-Meily, J. M. (2015). Psychological factors are associated with subjective cognitive complaints 2 months post-stroke. Neuropsychological rehabilitation, 27(1), 99-115. Doi: 10.1080/09602011.2015.1065280.

Solgajová, A., Vörösová, G., \& Zrubcová, D. (2017). Determinants of quality of life in patients after stroke. Ořetrovatel'stvo: teória, výskum, vzdelávanie [online], 2017, 1(1), p. 34-39. Available on: http://www.osetrovatelstvo.eu/archiv/2017-rocnik-7/cislo-1/determinanty-kvality-zivotapacientov-po-cievnej-mozgovej-prihode.

Teoh, V., Sims, J., \& Milgrom, J. (2009). Psychosocial predictors of quality of life in a sample of community-dwelling stroke survivors: a longitudinal study. Topics in stroke rehabilitation, 16(2), 157-166. Doi: 10.1310/tsr1602-157.

Truelsen, T. Nielsen, N., Boysen, G., \& Grønbaek, M. (2003). Self-reported stress and risk of stroke: the Copenhagen City Heart Study. Stroke, 34(4), 856-862. Doi: 10.1161/01.STR.0000062345.80774.40.

van Mierlo, M. L., Schröder, C., van Heugten, C. M., Post, M. W., de Kort, P. L., \& Visser-Meily, J. M. (2014). The influence of psychological factors on Health-R elated Quality of Life after stroke: a systematic review. International journal of stroke, 9(3), 341-348. Doi: 10.1111/ijs.12149.

van Mierlo, M. L., van Heugten, C. M., Post, M. W., Hoekstra, T., \& Visser-Meily, A. (2017) . Trajectories of health-related quality of life after stroke: results from a one-year prospective cohort study. Disability and rehabilitation, 40(9), 997-1006. Doi: 10.1080/09638288.2017.1292320.

van Mierlo, M. L., van Heugten, C.M., Post, M.W., de Kort, P.L., Visser-Meily, J. M. (2015). Psychological factors determine depressive symptomatology after stroke. Archives of physical medicine and rehabilitation, 96(6), 1064-1070. Doi: 10.1016/j.apmr.2015.01.022 
Visser, M. M., Aben, L., Heijenbrok-Kal, M. H., Busschbach, J. J., \& Ribbers, G. M. (2014). The relative effect of coping strategy and depression on health-related quality of life in patients in the chronic phase after stroke. Journal of rehabilitation medicine, 46(6), 514-519. Doi: 10.2340/165019771803.

Visser, M. M., Heijenbrok-Kal, M. H., van't Spijker, A., Oostra, K. M., Busschbach, J. J., \& Ribbers, G. M. (2015). Coping, problem solving, depression, and health-related quality of life in patients receiving outpatient stroke rehabilitation. Archives of physical medicine and rehabilitation, 96(8), 1492-1498. Doi: 10.1016/j.apmr.2015.04.007.

Visser, M. M., Rhebergen, M. L., Rinkel, G. J., van Zandvoort, M. J., \& Post, M. W. (2009). Long-term health-related quality of life after aneurysmal subarachnoid hemorrhage: relationship with psychological symptoms and personality characteristics. Stroke, 40(4), 1526-1529. Doi: 10.1161/STROKEAHA. 108.531277.

Wei, C., Zhang, F., Chen, L., Ma, X., Zhang, N., \& Hao, J. (2016). Factors associated with post-stroke depression and fatigue: lesion location and coping styles. Journal of neurology, 263(2), 269-276. Doi: $10.1007 /$ s00415-015-7958-2.

Wolters, G., Stapert, S., Brands, I., \& Van Heugten, C. (2010). Coping styles in relation to cognitive rehabilitation and quality of life after brain injury. Neuropsychological rehabilitation, 20(4), 587600. Doi: 10.1080/09602011003683836

World Health Organization. (2006). Working together for health. Switzerland: WHO Press, 2006.

\section{Acknowledgements}

This study was supported by the research project VEGA 1/0418/19 Coping strategies in recovery after stroke 